\title{
Cytomegalovirus and Langerhans Cell Histiocytosis: Is There a Link?
}

\author{
Maliheh Khoddami, ${ }^{1}$ Seyed-Alireza Nadji, ${ }^{2}$ Paria Dehghanian, ${ }^{3,}$ Mahsa Vahdatinia, ${ }^{4}$ and \\ Ahmad-Reza Shamshiri ${ }^{5}$ \\ ${ }^{1}$ Pediatric Pathology Research Center, Mofid Children's Hospital, Shahid Beheshti University of Medical Sciences, Tehran, IR Iran \\ 2 Virology Research Center, National Research Institute of Tuberculosis and Lung Diseases (NRITLD), Shahid Beheshti University of Medical Sciences, Tehran, IR Iran \\ 3 Pediatric Infections Research Center, Mofid Children's Hospital, Shahid Beheshti University of Medical Sciences, Tehran, IR Iran \\ ${ }_{4}^{4}$ Dediatric Infections Research Center, Mofid Children's Hospital, Shahid Beheshti University of Medical Sciences, Tehran, \\ ${ }^{5}$ Department of Community Oral Health, Dental Research Center, Dentistry Research Institute, Tehran University of Medical Sciences, Tehran, IR Iran \\ ${ }^{*}$ Corresponding author: Paria Dehghanian, Pediatric Infections Research Center, Mofid Children's Hospital, Shahid Beheshti University of Medical Sciences, P.O. Box: 1546815514, \\ Tehran, IR Iran. Tel: +98-2122227035, Fax:+98-2122227033, E. mail: paria_email@yahoo.com \\ Received 2015 February 13; Accepted 2015 November 29.
}

\begin{abstract}
Background: Langerhans cell histiocytosis is a rare proliferative histiocytic disease of unknown etiology. Histologically, it is characterized by granuloma-like proliferation of Langerhans-type dendritic cells derived from bone marrow. Many investigators have suggested the possible role of viruses such as Epstein-Barr virus, human herpesvirus-6 (HHV-6), herpes simplex virus (HSV) types 1 and 2, and Cytomegalovirus in the pathogenesis of Langerhans cell histiocytosis.

Objectives: In this study, we have investigated the presence of Cytomegalovirus in Langerhans cell histiocytosis in Iranian children.

Patients and Methods: In this retrospective study, we have investigated the presence of Cytomegalovirus DNA expression, using paraffinembedded tissue samples of 30 patients with Langerhans cell histiocytosis and 30 age and site-matched controls by qualitative Polymerase Chain Reaction (PCR) method.

Results: No significant difference in prevalence of Cytomegalovirus presence between patients and controls was found. Cytomegalovirus was found by qualitative PCR in only 2 (6.66\%) out of 30 patients and in $1(3.3 \%)$ of 30 control samples with a P value of 1(1.00 >0.05) using chi-square test with OR:2.07; 95\% CI of OR: 0.18-24.15.

Conclusions: Our findings do not support the hypothesis of a possible role for Cytomegalovirus in the pathogenesis of Langerhans cell histiocytosis.
\end{abstract}

Keywords: Langerhans Cell Histiocytosis, Cytomegalovirus, Polymerase Chain Reaction

\section{Background}

Clonal proliferation of histiocytes was reported in Langerhans cell histiocytosis (LCH) by Willman et al. in 1994 (1). Langerhans cells are a type of nonlymphoid mononuclear cells involved in inflammatory responses and also in neoplastic processes. They are immature dendritic cells which express lysosomal enzymes CD1a and S-100 protein and ultrastructurally contain racket shaped organelles of Birbeck granules (2). The etiology is unknown; however, environmental agents and viruses, especially epstein-barr virus (EBV), or vaccination, have been proposed to play a role in the pathogenesis of $\operatorname{LCH}(3,4)$. The role of $E B V$ as the etiologic agent of several malignancies is known and herpes viruses are shown to be responsible for persistent infection (5, 6 ). In addition, EBV and cytomegalovirus (CMV) are considered to be responsible for hemophagocytic syndromes in human with several inherited immunodeficiencies $(7,8)$. One study showed 30\% positivity for $C M V$ in $\mathrm{LCH}$ (9); however, others have failed to show any association with adenovirus, cytomegalovirus, Epstein-Barr virus, herpes simplex virus, human herpes virus type 6, human immunodeficiency virus, human T-cell leukemia virus types I and II, and parvovirus using PCR (10-12).

\section{Objectives}

In this study, we have investigated the presence of $C M V$ in LCH by qualitative PCR method. Our study is the first study performed on this subject in Iranian children.

\section{Patients and Methods}

\subsection{Patients and Controls}

Formalin-fixed, paraffin-embedded (FFPE) tissue samples of 30 patients with pathologic diagnosis of $\mathrm{LCH}$ were extracted from archive of pathology department of Mofid children's hospital in Tehran (one of the referral centers from all over the country) for a ten year period (2002 to 2012). The diagnosis of LCH was made by a pediatric pathologist, using the histological criteria mentioned in

Copyright (C) 2016, Growth \& Development Research Center. This is an open-access article distributed under the terms of the Creative Commons Attribution-NonCommercial 4.0 International License (http://creativecommons.org/licenses/by-nc/4.0/) which permits copy and redistribute the material just in noncommercial usages, provided the original work is properly cited. 
the pathology textbooks, i.e. granulomas composed of Langerhans cells with typical grooved nuclei mixed with eosinophils and other inflammatory cells. The diagnoses were confirmed using immunohistochemical technique for CD1a, S-100 protein and CD68 when available. All patients were Iranian and the age ranged between 2 months and 10 years. Thirty tissue samples with non LCH diagnoses were also selected (between the years 2002 and 2012) as age and site-matched controls to LCH cases.

\subsection{Nucleic Acid Extraction}

Paraffin was removed from the FFPE samples after undergoing xylene treatment, followed by two washes with pure ethanol. Total DNA was extracted from the air-dried pellet tissues according to the RTP® DNA/RNA virus mini kit procedure (Stratec molecular, Berlin, Germany). The extracted nucleic acid was stored at $-20^{\circ} \mathrm{C}$ until it underwent PCR.

\section{3. $P C R$}

To assess the quality of the extracted genome, as well as inhibition of PCR test, all extracted and stored nucleic acid underwent beta-globin PCR, using the PCO3/PCO4 primer set, as described previously with modifications in method (13). The beta-globin PCR was performed in syber green real-time PCR-melting curve format (Figure 1). To detect $C M V$, real-time PCR was performed using envelope glycoprotein B (gpUL55) gene primer sets amplifying 116 bp gene region of the virus genome (CMV-r ; 5'-AAGTACCCCTATCGCGTGTG-3'), CMV-f; 5'-ATGATGCCCTCRTCCARGTC -3', with an internal probe, CMV-P ; 5'FAM-TGGCCCAGGGTACGGATCTTATTCG-BHQ1-3') (14). Amplification of CMV gpUL55 genes was performed in reaction volumes of $20 \mu \mathrm{L}$ under the following conditions: first the samples underwent denaturation at $94^{\circ} \mathrm{C}$ for 10 minutes, followed by denaturation at $94^{\circ} \mathrm{C}$ for 10 seconds, followed by annealing and extension at $60^{\circ} \mathrm{C}$ for one minute, 50 cycles (Figure 2). Real-time PCR system CFX-96 (BIO-Rad, USA) with HS prime taq premix TaqMan reagent (GENETBIO, Korea) was used in real-time PCR assay. The limit detection of 5 genome copies of $C M V$ per reaction was determined by the real-time assay, using the serial dilutions of AmpliRun $₫$ CYTOMEGALOVIRUS DNA CONTROL (Vircell, Spain).

\subsection{Statistical and Ethical Considerations}

The achieved data were compared by chi-square (or Fisher's exact test if appropriate). Pvalue of less than 0.05 was considered to indicate statistical significance.

In this study, no ethical issues were involved; only the pathology reports were reviewed retrospectively, and the patients were anonymous. The articles used as references are valid and the information taken are reported unchanged.

\section{Results}

Thirty patients with pathologic diagnosis of LCH were included in this study. All patients were Iranians (16 males and 14 females) and the age ranged 2 months to 10 years. Age, sex and biopsy site of all patients are shown in Table 1. Thirty tissue samples with non LCH diagnoses were also selected as controls which were age and site-matched to $\mathrm{LCH}$ cases. CMVDNA was detected in only $2(6.66 \%) \mathrm{LCH}$ patients out of 30 cases (positive results in $6.66 \%$ and negative results in 93.34\%). In control group, we detected CMV virus in $1(3.3 \%)$ sample out of a total of 30 cases (positive results in $3.3 \%$ and negative results in $96.7 \%$ of controls) with a $\mathrm{P}$ value of $1.00(1.00>0.05)$ and OR: $2.07 ; 95 \%$ CI of OR: 0.18 - 24.15 which shows no significant difference in CMV prevalence results between LCH patients and controls. The LCH patients with positive result for $C M V$ expression were a 2 year old boy with frontal bone lesion and a 1 year old girl with chest skin lesion; the positive control was in a 6 yearold boy with skin biopsy diagnosed as pilonidal fistula.

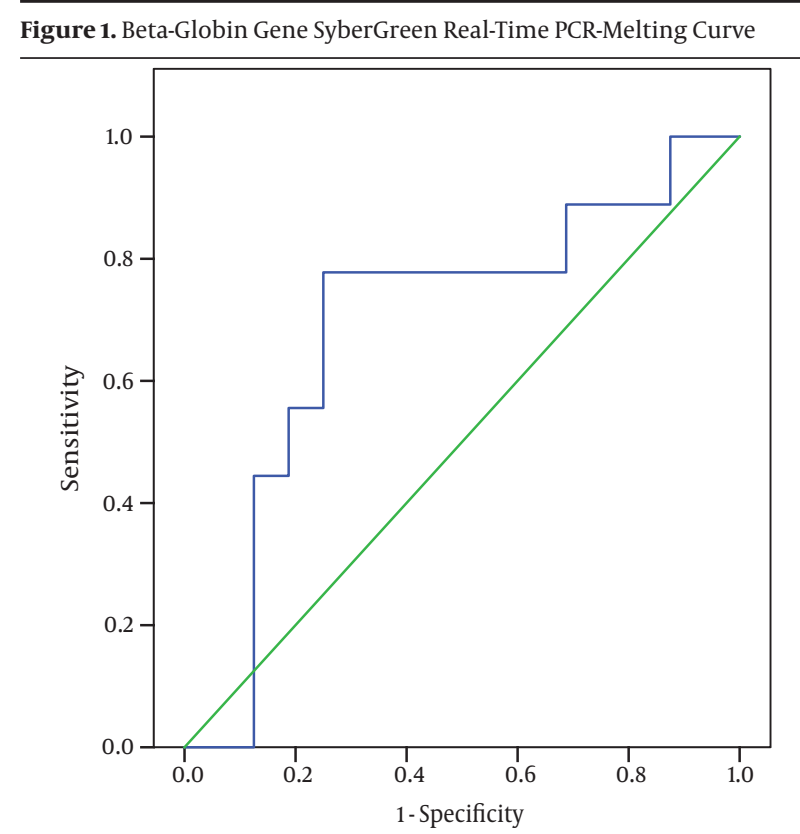

The graph shows that the melting temperature of beta-globin PCR product is around $82.5^{\circ} \mathrm{C}$.

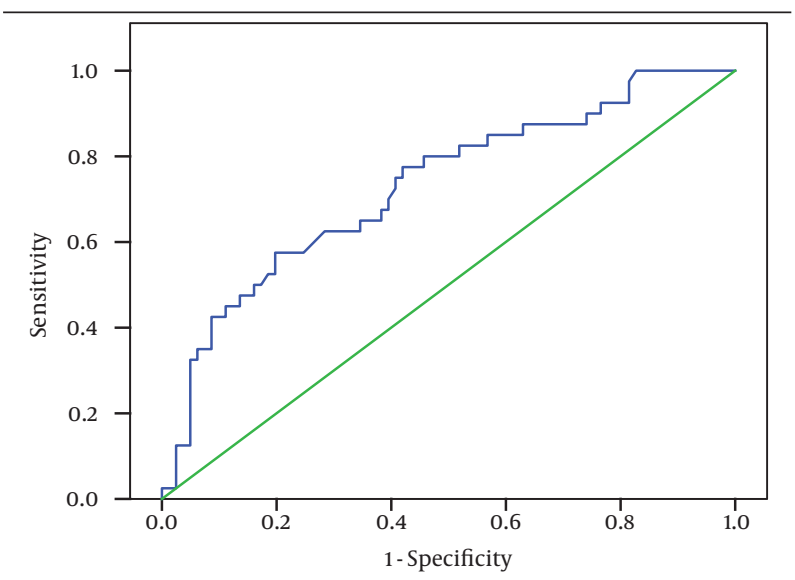

Figure 2. CMV Real-Time PCR Using Envelope Glycoprotein B (gpUL55) Gene Primer Sets 
Khoddami M et al.

\begin{tabular}{|c|c|c|c|}
\hline Age & Gender & Clinic/Biopsy Site & CMV \\
\hline $2 \mathbf{y}$ & Female & Lymph node & - \\
\hline $2 \mathbf{y}$ & Male & Mediastinal and neck mass & - \\
\hline $10 \mathrm{mo}$ & Male & Skin & - \\
\hline $1 \mathbf{y}$ & Male & Soft tissue, scalp mass & - \\
\hline $2 \mathbf{y}$ & Male & Frontal bone & + \\
\hline $11 \mathrm{mo}$ & Male & Mastoid bone & - \\
\hline $1 \mathbf{y}$ & Female & Skin, chest wall & + \\
\hline $3 \mathbf{y}$ & Male & Iliac bone & - \\
\hline $6 y$ & Female & Proximal tibia & - \\
\hline $10 y$ & Male & Skull and soft tissue & - \\
\hline $2 \mathbf{y}$ & Female & Parietal bone and soft tissue & - \\
\hline $2 \mathbf{y}$ & Male & Skin & - \\
\hline $8 \mathbf{y}$ & Male & Soft tissue, scalp & - \\
\hline $2 y$ & Female & Soft tissue, submandibular & - \\
\hline $2 \mathbf{y}$ & Male & Vertebral bone & - \\
\hline $7 y$ & Male & Clavicle and soft tissue & - \\
\hline 15 mo & Male & Abdominal mass & - \\
\hline $4 y$ & Female & Base of skull & - \\
\hline $2.5 y$ & Female & Right lobe of lung & - \\
\hline $8 \mathbf{y}$ & Female & Skin, abdomen & - \\
\hline $2 \mathrm{mo}$ & Female & Soft tissue & - \\
\hline $2 \mathbf{y}$ & Male & Soft tissue, scalp & - \\
\hline $3 \mathbf{y}$ & Female & Frontal bone and soft tissue & - \\
\hline $3 \mathbf{y}$ & Female & Soft tissue, scalp & - \\
\hline $2 y$ & Female & Metatarsal bone & - \\
\hline $16 \mathrm{mo}$ & Male & Skin & - \\
\hline $4 \mathrm{mo}$ & Female & Skin & - \\
\hline $1 \mathbf{y}$ & Female & Skin & - \\
\hline $1.5 \mathrm{y}$ & Male & Soft tissue, scalp & - \\
\hline $7 \mathbf{y}$ & Male & Soft tissue, perianal & - \\
\hline
\end{tabular}

\section{Discussion}

$\mathrm{LCH}$ is a rare disease involving clonal proliferation of bone marrow derived Langerhans cells which mostly affects children, particularly children younger than 5 years with an incidence of about 5 per 1,000,000 (2). Clinically, there are three overlapping clinical syndromes including multifocal multisystemic LCH (Letterer-Siwe syndrome), multifocal unisystemic LCH (hand-Schuller-Christian syndrome) and unifocal LCH (solitary eosinophilic granuloma) (2). Histologically, the findings are the same in various tissues, characterized by granulomas composed of a mixture of Langerhans cells, macrophages, eosinophils, multinucleated giant cells and lymphocytes $(15,16)$. The prognosis of LCH is influenced by the involved or-

gans and the age. Most adult patients with lung involvement usually have an indolent course of regress, whereas children need to be treated (17-20).

CMV can infect dendritic cells and Langerhans cells (2123). Kawakubo et al. (9) detected $C M V$ in lesional Langerhans cells in 30\% of 29 patients by immunochemistry, in situ hybridization, and PCR, indicating that release of cytokines stimulates Langerhans cell growth and induction of LCH. Jeziorski et al. (10), however, did not support the hypothesis of the role of $E B V, C M V$, or $H H V-6$, in the pathogenesis of LCH in their study. McClain et al. (11) also failed to find evidence of genomes for adenovirus, $C M V, E B V$, HSV, HHV-6, human immunodeficiency virus, human T-cell 
leukemia virus types I and II, and parvovirus in 56 cases of LCH employing in situ hybridization and PCR technique. We detected CMV DNA in only 2 patients with LCH (positive results in $6.66 \%$ and negative results in $93.34 \%$ ). Only one in our control group had CMV virus (positive results in $3.3 \%$ and negative results in $96.7 \%$ of controls), which could be attributed to a coincidence. The P value of 1.00 $(1.00>0.05)$ and OR: 2.07; 95\% CI of OR: $0.18-24.15$ indicates no significant difference in $C M V$ prevalence results between $\mathrm{LCH}$ patients and controls. This is in keeping with some other results reported in the literature $(10,12)$.

In previous studies (9-12) authors declared no limitations and the methods used included serology, immunochemistry, in situ hybridization, and PCR. However, immunochemistry and in situ hybridization for $C M V$ were not available to be employed in our study and the patients were not checked for the evidence of $C M V$ infection serologically (limitations in our study).

\subsection{Conclusions}

Our study is the first study performed in Iran on this subject and does not support the hypothesis of a role for $C M V$ in the pathogenesis of $\mathrm{LCH}$, in concordance with some other studies in the literature (10-12).

\section{Acknowledgments}

This study was conducted as dissertation by Paria Dehghanian under supervision of Maliheh Khoddami, to fulfill the requirements for pediatric pathology fellowship at Shahid Beheshti University of Medical Sciences and is financially supported by Pediatric Infections Research Center at Shahid Beheshti University of Medical Sciences. We thank Leila Poos-Ashkan and Pooneh Tavakoli for performing the PCR and Mojgan Shohadai for technical assistance.

\section{References}

1. Willman CL, Busque L, Griffith BB, Favara BE, McClain KL, Duncan $\mathrm{MH}$, et al. Langerhans'-cell histiocytosis (histiocytosis X)-a clonal proliferative disease. N Engl J Med. 1994;331(3):154-60. doi: 10.1056/NEJM199407213310303. [PubMed: 8008029]

2. Weiss LM. Histiocytic and dendritic cell proliferations. In: Knowles DM, editor. Neoplastic Hematopathology. Philadelphia: Lippincott Williams \& Wilkins; 2001. pp.1815-45.

3. Chen CJ, Ho TY, Lu JJ, Sheu LF, Lee SY, Tien CH, et al. Identical twin brothers concordant for Langerhans' cell histiocytosis and discordant for Epstein-Barr virus-associated haemophagocytic syndrome. Eur J Pediatr. 2004;163(9):536-9. doi: 10.1007/s00431-0041493-y. [PubMed:15243808]

4. Sakata N, Toguchi N, Kimura M, Nakayama M, Kawa K, Takemura T. Development of Langerhans cell histiocytosis associated with chronic active Epstein-Barr virus infection. Pediatr Blood Cancer. 2008;50(4):924-7. doi:10.1002/pbc.21249. [PubMed:17474115]

5. Purtilo DT. Epstein-Barr-virus-induced oncogenesis in immune- deficient individuals. Lancet. 1980;1(8163):300-3. [PubMed: 6101750]

6. Young LS, Rickinson AB. Epstein-Barr virus: 40 years on. Nat Rev Cancer. 2004;4(10):757-68. doi: 10.1038/nrc1452. [PubMed: 15510157]

7. Menasche G, Feldmann J, Fischer A, de Saint Basile G. Primary hemophagocytic syndromes point to a direct link between lymphocyte cytotoxicity and homeostasis. Immunol Rev. 2005;203:165-79. doi:10.1111/j.0105-2896.2005.00224.x. [PubMed:15661029]

8. Rigaud S, Fondaneche MC, Lambert N, Pasquier B, Mateo V, Soulas $\mathrm{P}$, et al. XIAP deficiency in humans causes an X-linked lymphoproliferative syndrome. Nature. 2006;444(7115):110-4. doi:10.1038/ nature05257. [PubMed: 17080092]

9. Kawakubo Y, Kishimoto H, Sato Y, Yanagimoto K, Tsuruta T, Ogawa Y, et al. Human cytomegalovirus infection in foci of Langerhans cell histiocytosis. Virchows Arch. 1999;434(2):109-15. [PubMed: 10071244]

10. Jeziorski E, Senechal B, Molina TJ, Devez F, Leruez-Ville M, Morand $P$, et al. Herpes-virus infection in patients with Langerhans cell histiocytosis: a case-controlled sero-epidemiological study, and in situ analysis. PLoS One. 2008;3(9):e3262. doi: 10.1371/journal. pone.0003262. [PubMed:18810271]

11. McClain K, Jin H, Gresik V, Favara B. Langerhans cell histiocytosis: lack of a viral etiology. Am J Hematol. 1994;47(1):16-20. [PubMed: 8042610]

12. McClain K, Weiss RA. Viruses and Langerhans cell histiocytosis: is there a link? BrJ Cancer. 1994;23:eS34.

13. Saiki RK, Bugawan TL, Horn GT, Mullis KB, Erlich HA. Analysis of enzymatically amplified beta-globin and HLA-DQ alpha DNA with allele-specific oligonucleotide probes. Nature. 1986;324(6093):163-6. doi: 10.1038/324163a0. [PubMed: 3785382]

14. Payne DA, Wimmer DB, Emmons J, Hernandez AK. Cytomegalovirus-Antigenemia-Positive and Polymerase-Chain-Reaction-Negative Transplant Patient. Lab Med. 2008;39(6):341-2. doi: 10.1309/ nhkbj8ufm8hkyjrx.

15. Lichtenstein L. Histiocytosis X; integration of eosinophilic granuloma of bone, Letterer-Siwe disease, and Schuller-Christian disease as related manifestations of a single nosologic entity. AMA Arch Pathol. 1953;56(1):84-102. [PubMed:13057466]

16. The French Langerhans' Cell Histiocytosis Study Group A multicentre retrospective survey of Langerhans' cell histiocytosis: 348 cases observed between 1983 and 1993 . Arch Dis Child. 1996;75(1):17-24. [PubMed: 8813865]

17. Ladisch S. Langerhans cell histiocytosis. Curr Opin Hematol. 1998;5(1):54-8. [PubMed: 9515204]

18. Laman JD, Leenen PJ, Annels NE, Hogendoorn PC, Egeler RM. Langerhans-cell histiocytosis 'insight into DC biology'. Trends Immunol. 2003;24(4):190-6. [PubMed:12697451]

19. Ninaber M, Dik H, Peters E. Complete pathological resolution of pulmonary Langerhans cell histiocytosis. Respirol Case Rep. 2014;2(2):76-8. doi: 10.1002/rcr2.54. [PubMed: 25473573]

20. Berber A Rare Disease in Adult: Langerhans Cell Histiocytosis. World J Oncol. 2013;4:165-8.

21. Hertel L, Lacaille VG, Strobl H, Mellins ED, Mocarski ES. Susceptibility of immature and mature Langerhans cell-type dendritic cells to infection and immunomodulation by human cytomegalovirus. JVirol. 2003;77(13):7563-74. [PubMed:12805456]

22. Lee AW, Hertel L, Louie RK, Burster T, Lacaille V, Pashine A, et al Human cytomegalovirus alters localization of MHC class II and dendrite morphology in mature Langerhans cells. J Immunol. 2006;177(6):3960-71. [PubMed:16951359]

23. Senechal B, Boruchov AM, Reagan JL, Hart DN, Young JW. Infection of mature monocyte-derived dendritic cells with human cytomegalovirus inhibits stimulation of T-cell proliferation via the release of soluble CD83. Blood. 2004;103(11):4207-15. doi: 10.1182/ blood-2003-12-4350. [PubMed: 14962896] 